\title{
Peculiarities of successional changes of xylotrophic basidiomycetes during decomposition of dominant tree species of forest formations of the Pitsunda-Myussera Reserve of the Republic of Abkhazia
}

\author{
Sofia Khacheva* \\ Institute of Ecology of the Academy of Sciences of Abkhazia, Abkhaz State University
}

\begin{abstract}
The article is about the biodiversity of xylotrophic fungi of oak and hornbeam forests of Abkhazia and related destructive processes of the main forest-forming species (oak and hornbeam). The species composition of fungi subjected to phytopathogenic and saprotrophic methods of decomposition was determined. The species composition of mycobiota, causing wood xylolysis practically up to the last stages of decomposition, has been determined. Key words: biodiversity, xylotrophic fungi, succession, Republic of Abkhazia
\end{abstract}

\section{Introduction}

One of the most important problems in the field of biology is the problem of the decomposition of complex organic substances in natural conditions. The processes of accumulation and decomposition of dead organic residues are subject to significant fluctuations depending on a number of factors: the composition of vegetation, climatic features, etc. [1].

The decomposition of organic substances is caused by the vital activity of soil organisms, especially bacteria, fungi and actinomycetes. Currently, there are a number of studies showing that the decomposition of persistent ligno-cellulose compounds in nature is realized by certain groups of fungi, mainly higher basidial and marsupials. These groups of fungi have a set of enzymes that can affect resistant plant compounds.

The aim of this work was to study the biodiversity of xylotrophic fungi, the ecological patterns of their dispersal and to identify the main destructors of broadleaved formations of the Pitsunda-Müsser Reserve of Abkhazia.

The Republic of Abkhazia occupies the central part of the Black Sea coast of the Caucasus, and here, in a relatively small area of the Western Caucasus, there is all the diversity of soil, climate and vegetation from subtropics to eternal snows. The total area of protected lands in Abkhazia is almost $27 \%$ of the country's territory [2-3].

The research was conducted on the territory of the Pitsunda-Mussera Reserve of the Republic of Abkhazia, which was establised in 1966, its area is 3761 hectares. Due to the heterogeneity of ecotopological conditions phyto landscapes of the territory under study are highly diverse (Kolakovsky et al., 1987) [4].

\section{Material and research methods}

The forest vegetation of the Müsser Upland is one of the most valuable objects under protection of the biological complex of the Pitsunda-Müsser Reserve. Mussera forests are represented by indigenous (climax) types of biogeocenoses, formed on several isolated ancientmarine, now dissected by ravines, conglomerate terraces and adapted to the corresponding relatively stable physical and geographic conditions [4]. (Kolakovsky et al., 1987). Positive terrain elements are mainly covered by oak groves of Georgian oak (Quercus iberica Stev.). Less dry and poorly illuminated ecotopes are mainly represented by forests dominated by hornbeam (Carpinus caucasica Grossh), chestnut and beech. Oak is often a part of hornbeam-chestnut forests.

Studies were conducted in broad-leaved mixed forests of hornbeam, oak, with evergreen undergrowth of Rhododendron ponticum (Rhododendron ponticum L.), blackberry, and butcher's broom Ruscus colchicus. The second tier is formed by hornbeam, strawberry tree (Arbutus andrachne L.), chestnut, and occasionally yew berry. The altitude range of the research is from 80-90 to $122 \mathrm{~m}$ above sea level. Geographic coordinates of the study area: Sq. 1-3 - Mussera (Q1: 43ํำ $45.92^{\prime \prime} \mathrm{N}$,

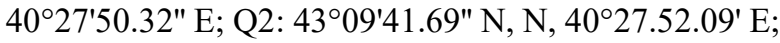
Q3: 4309'11.30" N, 40²6'31.83" E); Q4: Ldzaa $\left(43^{\circ} 11^{\prime} 52.42^{\prime \prime} \mathrm{N}, 40^{\circ} 19^{\prime} 01.14^{\prime \prime} \mathrm{E}\right)$.

Mycobiota of xylotrophic basidiomycetes were studied during the June to October growing seasons from 2014 to 2018. Inventory of fungi biota of the main forest-forming formations of the Pitsunda-Müsser Reserve of Abkhazia was carried out according to standard methods [4]. The collected material was identified using identifiers and reference guides. Species

\footnotetext{
*Corresponding author: khacheva2014@yandex.ru
} 
are listed according to the Index Fungorum nomenclature database (2020) and the 10th edition of the Ainsworth and Bisbee Dictionary of Fungi [5].

Fungi were counted and collected both on dead wood of different decomposition stages and on living trees. The five-point scale proposed by P. Gordienko was used to determine the stages of wood degradation and, accordingly, to identify the successional stages of fungal communities. Determination of wood degradation stages was indicated both for small twigs and for large dead wood, which is a complex of microhabitats differing in microclimate conditions, humidity, etc. Different areas of woody substrate are inhabited by different species of xylotrophic fungi and decompose at different rates. In this case, the degree of wood degradation within one unit of substrate can be estimated differently, from 2 to 4 points [6].

\section{Results and discussion}

The colonization of wood residues with xylotrophic basidiomycetes is one of the main factors controlling the intensity of biological decomposition of wood in natural conditions [7]. In the process of destruction, the physical and chemical properties of wood change, and the amount of those components that are available to fungi as nutrients decreases. The wood is being depleted, and the metabolic products of fungi are gradually changing biochemically. At the same time, the environment of micro-habitats changes significantly, new properties of wood become favorable for other types of fungi, a succession sequence occurs [8]. As a result of the competition of fungi, a complex of species corresponding to the degree of decomposition of wood is formed. Depending on the trophic affiliation, the succession of xylotrophic fungi can be divided into two groups: successions starting with a lesion of a living tree and successions on dead wood.

Based on this, V.A. Mukhin [9] identifies two ways of biological decomposition of wood: phytopathogenic and saprotrophic. In a typical form, the phytopathogenic way of wood decomposition is observed when living trees are affected by parasitic xylotrophic basidiomycetes, which are able to develop as saprotrophs after the death of trees [9]. Due to the activity of parasitic xylotrophs, the life expectancy of trees decreases, and thus the entry of wood into the "decomposition chains" of forest biogeocenoses is accelerated [9]. The destruction of wood by saprotrophic type begins with the colonization of wood with imperfect and marsupial fungi, and then basidiomycetes, which will determine the rate of decomposition of wood in forest ecosystems [10].

As a result of the studies carried out in the deciduous forests of the Myussera Upland 84 species of xylotrophic fungi were identified which belong to 57 genera, 20 families, 9 orders. In terms of the number of species the orders Polyporales (52 species) and Hymenochaetales (13) dominate, accounting for 65 species or $77.4 \%$ of their total number. The rest of the orders include from one to six species. The largest number of genera noted in the following families: Polyporaceae (17 genera), Hymenochaetaceae (6), Meruliaceae (6), Fomitopsidaceae (5), Phanerochaetaceae (4), which is $66.7 \%$ of the revealed number of genera.

The largest genus is Trametes numbering in seven species $(8.3 \%)$. The below mentioned genera contain from 2 to 4 species: Ganoderma (4), Steccherinum (3), Phellinus (3), Clavulina (2), Fomitiporia (2), etc. They are 14 in number and include 35 species, which is $41.7 \%$ of the identified part of the mycobiota. The remaining 42 genera contain one species each, which is $50 \%$ of the studied biota of aphyllophoroid fungi

The spread of xylotrophic fungi is determined by the presence of a substrate in a state suitable for colonization, and, first of all, by the optimal values of humidity and temperature. The dissection of the relief, the alternation of exposures of the slopes determine a large mosaic of ecological conditions, which is reflected in the species composition of the biota of xylotrophic fungi. The presence of species with the highest ecological valence was noted on the territory of the reserve: Daedalea quercina, Stereum hirsutum, Trichaptum biforme, Hymenochaeta rubiginosa, Daedaleopsis tricolor, Ganoderma applanatum, Trametes gibbosa, Stereum subtomentosum, and other forms of Irpex lacionts. However, despite the presence of eurybionts, each forest formation is characterized by the presence of formation-specific species due to the diversity of ecological conditions, trophic preferences, and competitive relationships of xylotrophs. These species include: Fistulina hepatica (Schaeff.) With., Phylloporia ribis (Schumach.) Ryvarden, Antrodia macra (Sommerf.) Niemelä, Radulodon licentii (Pilát) Ryvarden, Ceriporia excelsa S. Lundell ex Bermason pulto. et MA Curtis) Nicol., Bondarcevomyces taxi (Bondartsev) Parmasto et al.

The following species are new to the Caucasus region: Antrodia malicola, Ceriporia tarda, Ceriporiopsis resinascens, Climacodon pulcherrimus, Hericium cirrhatum, Tomentella terrestris, Tremella foliacea.

In the studied forest formations, wood decomposition happens in two ways: phytopathogenic and saprotrophic. The phytopathogenic one involves: Ganoderma applanatum, G. lucidum, G. resinaceum, Laetiporus sulphureus, Fomitiporia robusta, Fistulina hepatica, Oxyporus populinus, Picipes badius, Pseudoinonotus dryadeus (10.7\% of fungi). The saprotrophic way of decomposition involves $89.3 \%$ of the total number of fungal species.

The following number of fungi varieties was revealed on the main forest-forming species: on oak (40 species), on hornbeam (56 species). The highly specialized species for Quercus iberica are: Fistulina hepatica, Daedalea quercina, Hymenochaete rubiginosa, Stereum gausapatum, etc.

In the studied forest formations, the decomposition of wood is carried out in two ways: phytopathogenic and saprotrophic. The phytopathogenic pathway of decomposition involves: Ganoderma applanatum, $G$. 
lucidum, G. resinaceum, Laetiporus sulphureus, Fomitiporia robusta, Fistulina hepatica, Oxyporus populinus, Picipes badius, Pseudoinonotus dryadeus (10.7\% of fungi). The saprotrophic decomposition involves $89.3 \%$ of the total number of fungal species. On the main forest-forming species, it was revealed: on oak (40 species), on hornbeam (56 species).

Highly specialized species to Quercus iberica are Fistulina hepatica, Daedalea quercina, Hymenochaete rubiginosa, Stereum gausapatum, etc.

The analysis of successional shifts of xylotrophic fungi allowed us to establish the dominant fungal complex that destructs Quercus iberica deadwood in the broad-leaved forests of the reserve (Fig. 1).

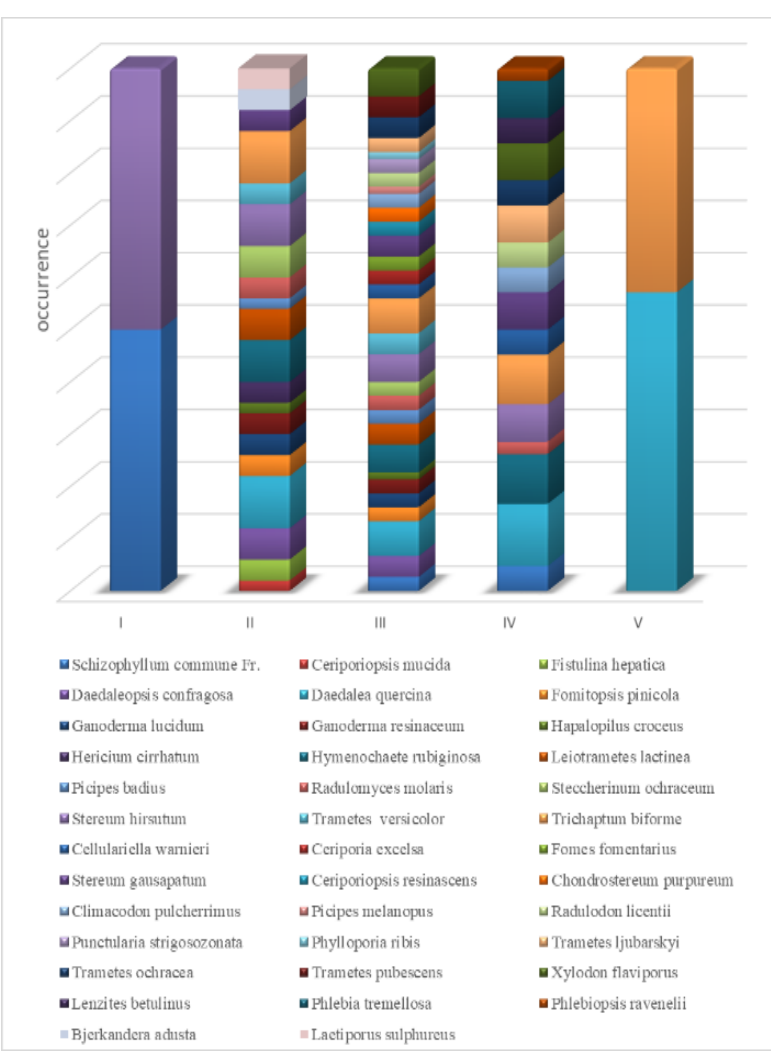

Fig. 1. Successions of xylotrophic fungi during the destruction of oak wood

56 species of xylotrophic fungi are involved in the decomposition of Carpinus caucasica deadwood. During the first stage of destruction, Schizophyllum commune dominates. From the second to the fourth stage of destruction, Trichaptum biforme, Stereum hirsutum, and Stereum subtomentosum prevail with an abundance of 4-5 points (Fig. 2).

On the dead wood of other tree species are represented Bondarcevomyces taxi, Phellinidium ferrugineofuscum, Trametes trogii, Trametes versicolor, etc.

Out of the 78 species of xylotrophic fungi identified in the stump and dead wood group, 72 species (92.3\%) belong to white rot (lignin-destroying) fungi, and 6 species $(7.7 \%)$ are cellulose-destroying, i.e., cause brown rot. The remaining species are represented by forest floor saprotrophs: Clavaria fumosa, Clavulina cinerea, C. coralloides, Coltricia perennis, and facultative parasites: Tremella foliacea, T. mesenterica.

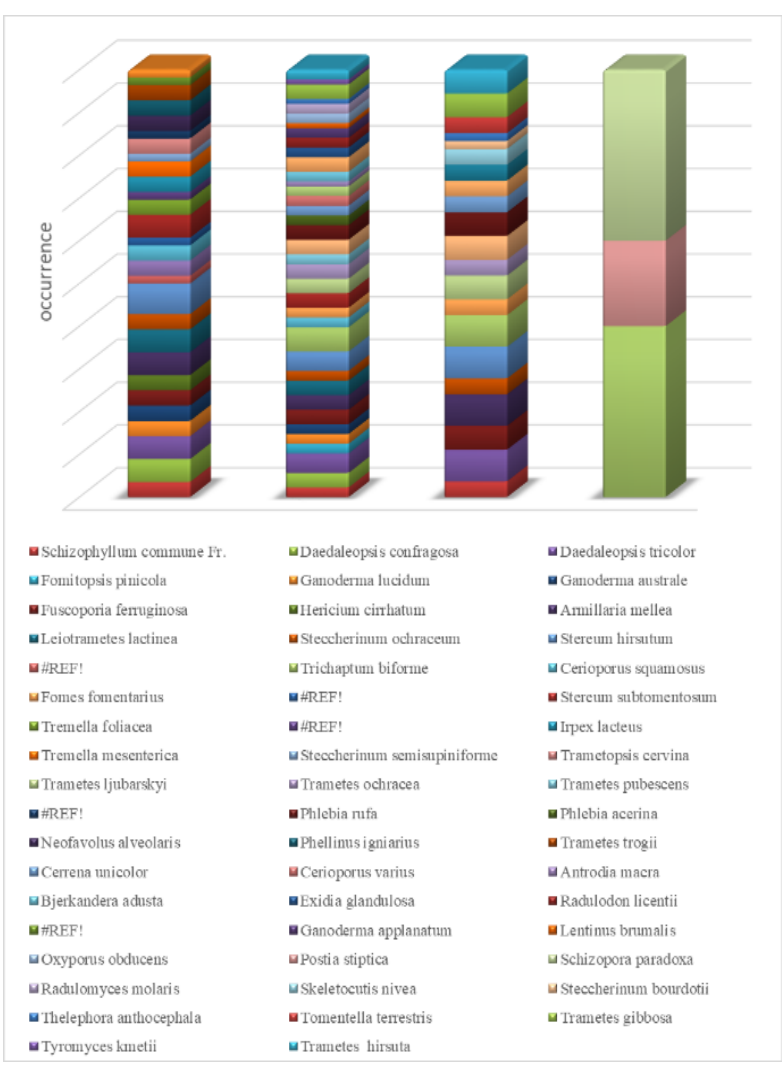

Fig. 2. Successions of xylotrophic fungi during the destruction of hornbeam wood

\section{Conclusion}

Thus, in the broad-leaved formations of the PitsundaMyussera Reserve, the saprotrophic type of wood destruction prevails. The intensity of the decomposition process is influenced by the physicochemical characteristics of the condition of the wood, the competitive relationship between individual types of fungi, the variety of environmental conditions within the substrate units.

The successional changes of fungi accelerate the decomposition process, but the dominant species are of decisive importance. In certain ecotopes, communities of destructors are formed, specializing in the decomposition of species prevailing in the stand [6].

In the studied forest formations, the main oak destructors are: Daedalea quercina, Fomes fomentarius, Ganoderma applanatum, Trametes gibbosa, Trichaptum biforme. The decomposition of hornbeam wood is dominated by the following types of fungi: Daedaleopsis tricolor, Stereum hirsutum, Trichaptum biforme, Daedaleopsis confragosa, Stereum subtomentosum, Armillaria mellea.

The products of biological decomposition of wood will be determined depending on the way in which the destruction of wood substrates was carried out. In the broad-leaved forests of the reserve, lignin-destroying 
fungi predominate $(92.3 \%)$, causing in corrosive decomposition of wood.

\section{References}

1. V.Ya. Chastukhin, M.A. Nikolaevskaya, Biological decay and resynthesis of organic matter in nature (Leningrad, 1969)

2. V.E. Sokolov, E.E. Syroechkovsky, Reserves of the Caucasus (Moscow, 1990)

3. A.A. Kolakovsky, S.M. Bebiya G.F. Urushadze, et al. Pitsunda-Mussersky Nature Reserve (Moscow, 1987)

4. A. Bondartsev, Tinder fungi European part of Russia and the Cancasus (Moscow; Leningrad, 1953)

5. P.M. Kirk, P.F. Cannon, D.W. Minger, J.A. Stalpers, Dictionary of the fungi. Oxon: CAB Intern. (2008)

6. M.A. Safonov, Community structure of xylotrophic fungi (Yekaterinburg, 2003)

7. E.V. Bryndina, Ecology of wood biodegradation processes (Yekaterinburg), 31-41 (2000)

8. V. Ripachek, Biology of wood-destroying fungi. M. (1967)

9. V.A. Mukhin, Biota of xylotrophic basidiomycetes of the West Siberian Plain (Yekaterinburg, 1993)

10. N.T. Stepanova, V.A. Mukhin, Fundamentals of the ecology of wood-destroying fungi (Moscow, 1979) 